\title{
KOGO „ULECZY” KRAJOWY OŚRODEK ZAPOBIEGANIA ZACHOWANIOM DYSSOCJALNYM?
}

Problematyka prawnokarnej reakcji wobec sprawców przestępstw seksualnych jest obecna w dyskursie społecznym, politycznym i naukowym od dłuższego czasu ${ }^{1}$. Przy walnym udziale mediów ${ }^{2}$, karmiących się postawami populistycznymi, które ze sprawców przestępstw seksualnych uczyniły niemal wroga publicznego numer jeden, w okresie ostatniego dziesięciolecia kilkakrotnie nowelizowano system prawa karnego w Polsce w zakresie prawnokarnej reakcji wobec sprawców przestępstw seksualnych ${ }^{3}$. Krytyka, jaka spadała na ustawodawcę za każdym razem po uchwaleniu kolejnej ustawy nowelizujacej, była w przeważającej mierze druzgocąca ${ }^{4}$. Trudno znaleźć choćby jednego

${ }^{1}$ Zob. m.in. M. Filar, „Druga” nowelizacja Kodeksu karnego w zakresie tzw. przestepstw seksualnych, w: M. Kosek, J. Słyk (red.), W trosce o rodzinę. Księga pamiatkowa ku czci Profesor Wandy Stojanowskiej, C. H. Beck 2008, s. 88 i n.; idem, Seksualne wykorzystywanie dzieci $w$ świetle polskiego kodeksu karnego (na tle prawnoporównawczym), „Dziecko Krzywdzone” 2002, $\mathrm{nr}$ 1, s. 40 i n.; P. Kiziukiewicz, Problematyka zgodności z Konstytucja RP środka karnego obowiazku powstrzymania się od przebywania $w$ określonych środowiskach lub miejscach, zakazu kontaktowania się z określonymi osobami lub zakazu opuszczania określonego miejsca pobytu bez zgody sqdu (cz. 1), „Palestra” 2009, nr 11-12, s. 19 i n.; M. Melezini, A. Sakowicz, Środek karny $w$ postaci obowiazku powstrzymania się od przebywania w określonych środowiskach lub miejscach, zakazu kontaktowania się z określonymi osobami lub zakazu opuszczania określonego miejsca pobytu bez zgody sqdu, „Czasopismo Prawa Karnego i Nauk Penalnych” 2008, z. 2, s. 195 i n.; R. Stefański, Środek karny zakazu prowadzenia działalności zwiazanej z wychowaniem, leczeniem, edukacja matoletnich lub z opiekq nad nimi, „Prokuratura i Prawo” 2007, nr 7-8, s. 42 i n.

${ }^{2}$ Zob. m.in. http://www.tvn24.pl/wiadomosci-z-kraju,3/90-pedofilow-wyjdzie-na-wolnosc-w-przyszlym-roku,276339.html; http://www.polityka.pl/kraj/analizy/1525333,1,pedofil-zabojca-wychodzi-na-wolnosc.read.

${ }^{3}$ M.in. ustawą z 27 lipca 2005 r. o zmianie ustawy - Kodeks karny, ustawy - Kodeks postępowania karnego i ustawy - Kodeks karny wykonawczy, Dz. U. 2005, Nr 163, poz. 1363; ustawa z 29 lipca 2005 r. o przeciwdziałaniu przemocy w rodzinie, Dz. U. 2005, Nr 180, poz. 1493; ustawa z 5 listopada 2009 r. o zmianie ustawy - Kodeks karny, ustawy - Kodeks postępowania karnego, ustawy - Kodeks karny wykonawczy, ustawy - Kodeks karny skarbowy oraz niektórych innych ustaw, Dz. U. 2009, Nr 206, poz. 1589, oraz ustawą z 10 czerwca 2010 r. o zmianie ustawy o przeciwdziałaniu przemocy w rodzinie oraz niektórych innych ustaw, Dz. U. 2010, Nr 125, poz. 842.

${ }^{4}$ M. Filar, „Druga” nowelizacja..., s. 88; J. Długosz, w: M. Królikowski, R. Zawłocki (red.), Kodeks karny. Część ogólna. Komentarz do art. 32-116, t. 2, Warszawa 2010, s. 738; J. Warylewski, Reakcja karna na przestepstwa seksualne, „Przegląd Więziennictwa Polskiego”, nr 54, 2007, s. 3839; A. Golonka, Nowe oblicze walki z pedofiliq w świetle nowelizacji kodeksu karnego, „Palestra” 2008, nr 3-4, s. 39; T. Pudo, Nowe regulacje karne dotyczqce przestepstw zwiqzanych z pedofilia, „Państwo i Prawo” 2007, z. 4, s. 66-67. 
entuzjastę takich rozwiązań, jak art. 106a k.k. lub też art. 95a k.k. w brzmieniu obowiązującym przed 8 czerwca 2010 r. ${ }^{5}$ Nie umknęło uwadze komentatorów, że modus operandi ustawodawcy przy uchwalaniu kolejnych nowelizacji sprowadzał się do „przepychania” naprędce przez tok prac ustawodawczych projektów ustaw, po to, aby w niedalekiej przyszłości przyjęte rozwiązania, pod naporem miażdżącej krytyki, poprawiać 6 .

Pomimo tylu dotkliwych niepowodzeń rodzimego prawodawcy na polu walki ze sprawcami przestępstw seksualnych, 13 grudnia 2013 r. została podpisana przez prezydenta ustawa z 22 listopada 2013 r. o postępowaniu wobec osób z zaburzeniami psychicznymi stwarzających zagrożenie życia, zdrowia lub wolności seksualnej innych osób, która weszła w życie 22 stycznia 2014 r. ${ }^{7}$ $\mathrm{Z}$ uwagi na determinację środowisk politycznych, na czele z Ministerstwem Sprawiedliwości, która w rezultacie doprowadziła do relatywnie szybkiego zakończenia prac ustawodawczych nad ww. ustawa, warto przyjrzeć się bliżej wprowadzonym rozwiązaniom.

Przed przystapieniem do merytorycznej analizy poszczególnych zapisów wskazanego aktu prawnego należy jeszcze pokrótce wspomnieć o genezie i okolicznościach powstania samego projektu. Wszystkiemu „winni” są sprawcy skazani na karę śmierci, którym ustawą z 7 grudnia 1989 r. o amnestii ${ }^{8}$ zamieniono wyroki śmierci na karę 25 lat pozbawienia wolności. W $2013 \mathrm{r}$. media (w tym, niestety, także i tzw. media poważne i opiniotwórcze) podjęły temat zbliżającego się zakończenia wykonywania tych kar przez wspomnianych sprawców ${ }^{9}$. Doniesienia medialne w zdecydowanej większości trudno było ocenić inaczej, niż jako kreślące obraz zbliżającego się wszechobecnego zagrożenia i kreujące w ten sposób atmosferę wszechogarniającego strachu przed zbliżajacym się opuszczeniem zakładów karnych przez drapieżców seksualnych, czyhających, aby przy najbliższej nadarzającej się okazji popełnić kolejne napawajace odrazą przestępstwo. Nie trzeba było długo czekać, aby w aurze narastającego poczucia zagrożenia i strachu, na żyznym gruncie tychże, zrodziły się idee (które trudno określić inaczej niż populistyczne) zapobiegnięcia mającym niechybnie zaistnieć czynom, przez uchwalenie rozwiązań,

${ }^{5}$ Z. Ćwiąkalski, w: A. Zoll (red.), Kodeks Karny. Część ogólna. Komentarz, t. 1, Warszawa 2007, s. 1071; N. Kłączyńska w: J. Giezek (red.), Kodeks karny. Część ogólna. Komentarz, Warszawa 2007, s. 625; A. Golonka, op. cit., s. 39; T. Pudo, op. cit., s. 66-67; M. Filar, „Druga” nowelizacja..., s. 88; J. Długosz, op. cit., s. 738; J. Warylewski, op. cit., s. 38-39; J. Malec, Problemy zwiqzane ze środkiem zabezpieczajacym wobec sprawców przestepstw przeciwko wolności seksualnej, „Przegląd Więziennictwa Polskiego”, nr 50, Warszawa 2006, s. 43-48.

${ }^{6}$ Zob. m.in. M. Filar, Rola mediów w kreowaniu zagrożeń $i$ sprzyjaniu populizmowi, „Archiwum Kryminologii”, t. 29-30, 2007-2008, s. 489-493; zob. także: J. Czapska, S. Waltoś, O polskim populizmie penalnym, w zwiazku z ksiażka J. Pratta "Penal populism», uwag kilka, w: K. Krajewski (red.), Nauki penalne wobec problemów wspótczesnej przestępczości. Ksiega jubileuszowa z okazji 70. rocznicy urodzin Profesora Andrzeja Gaberle, Warszawa 2007, s. 397-412.

${ }^{7}$ Dz. U. 2014, poz. 24. Zob. http://orka.sejm.gov.pl/proc7.nsf/ustawy/1577_u.htm; http://www. sejm.gov.pl/Sejm7.nsf/PrzebiegProc.xsp?id=3C090B1BF0741E83C1257BAC004EED94.

${ }^{8}$ Dz.U. 1989, Nr 64, poz. 390; http://isap.sejm.gov.pl/DetailsServlet?id=WDU19890640390.

${ }_{9}$ Zob. m.in. http://www.tvn24.pl/wiadomosci-z-kraju,3/90-pedofilow-wyjdzie-na-wolnosc-w-przyszlym-roku,276339.html; http://www.polityka.pl/kraj/analizy/1525333,1,pedofil-zabojcawychodzi-na-wolnosc.read. 
które nie pozwolą odzyskać wolności wspomnianym sprawcom ${ }^{10}$. Ponieważ w grę nie wchodziło jakiekolwiek przedłużenie skazanym długości odbywanych przez nich kar pozbawienia wolności, zdecydowano się na prowadzenie wobec owych szczególnie niebezpiecznych sprawców działań terapeutycznych po zakończeniu odbywania przez nich kary pozbawienia wolności, w oparciu o ich aktualny stan zdrowia psychicznego i cechy osobowości ${ }^{11}$.

Sama idea tego rodzaju regulacji nie jest rzecz jasna żadna nowościa. Wspomniane unormowania nazywane są zbiorczo „prawem o postępowaniu ze szczególnie niebezpiecznymi sprawcami przemocy seksualnej” (ang. sexually violent predator (SVP) legislation) ${ }^{12}$. Są to rozwiązania wpisujace się w jeden z wyróżnianych modeli prawnokarnej reakcji wobec sprawców przestępstw seksualnych - model ochrony społeczności lokalnej ${ }^{13}$. Podstawowym celem regulacji SVP jest kontrola sprawców opuszczajacych zakład karny. W ramach tych uregulowań na szczególną uwagę zasługują mechanizmy prawne pozwalające na przedłużenie pobytu sprawców przestępstw seksualnych w zakładzie karnym, a w niektórych wypadkach - nawet na umieszczanie ich na czas nieokreślony po opuszczeniu więzienia w zakładach zamkniętych. Zgodnie z wspomnianymi regulacjami istnieje możliwość po uprzednim dokonaniu analizy akt sprawy, przeprowadzeniu wywiadów i badań psychologicznych, psychiatrycznych i seksuologicznych, a przede wszystkim po dokonaniu przez biegłych oceny ryzyka ponownego popełnienia przestępstwa seksualnego przez sprawcę - uznania osoby za szczególnie niebezpieczną i na tej podstawie skierowanie jej do odpowiedniego ośrodka na czas nieokreślony (ang. civil commitment $)^{14}$. Zazwyczaj procedura SVP jest wszczynana w okresie od 3 do 6 miesięcy przed opuszczeniem zakładu karnego przez więźnia cierpiącego na poważne zaburzenia sfery seksualnej. Osoby uznane za szczególnie niebez-

\footnotetext{
${ }^{10} \mathrm{Na}$ taki mechanizm wskazywali m.in. M. Filar, Rola mediów..., s. 489-493; zob. także: J. Czapska, S. Waltoś, op. cit., s. 397-412.

${ }_{11}$ Zob. uzasadnienie Rządowego projektu ustawy o postępowaniu wobec osób z zaburzeniami psychicznymi stwarzających zagrożenie życia, zdrowia lub wolności seksualnej innych osób; druk sejmowy Sejmu VII Kadencji nr 1577; dostępny na: http://www.sejm.gov.pl/Sejm7.nsf/druk. $\mathrm{xsp}$ ?nr=1577.

12 A. Morawska, Strategie postepowania ze sprawcami przestepstw seksualnych wobec dzieci na przyktadzie wybranych krajów, „Dziecko Krzywdzone” 2004, nr 7, s. 3.

${ }^{13}$ K. Lewandowska, Karać czy leczyć? Strategie postępowania ze sprawcami przestepstw seksualnych wobec dzieci na przyktadzie wybranych krajów, „Dziecko Krzywdzone” 2007, nr 18, s. 2-14; A. Morawska, op. cit., s. 1-14.

${ }^{14}$ Zob. m.in. J. E. B. Myers, Societal Self-Defense. New Laws to Protect Children from Sexual Abuse, „Child Abuse \& Neglect” 20, 1996, nr 4, s. 255-258; K. Tregilgas, Sex Offender Treatment in the United States: The Current Climate and an Unexpected Opportunity for Change, „Tulane Law Review" 2010, February, s. 743-745; C. Calkins Mercado, J. R. P. Ogloff, Risk and the Preventive Detention of Sex Offenders in Australia and the United States, „International Journal of Law and Psychiatry" 30, 2007, s. 50-51; E. M. Rollman, "Mental illness": A Sexually Violent Predator is Punished Twice for One Crime, „The Journal of Criminal Law \& Criminology” 88, 1998, nr 3, s. 985-1014; J. Petrila Because They do Horrible Things: Fear, Science, and the Erosion of Civil Liberties in Sexually Violent Predator Proceedings, „The Journal of Psychiatry \& Law” 36, 2008, Fall, s. 359-388; K. M. Carlsmith, J. Monahan, A. Evans, The Function of Punishment in the "Civil” Commitment of Sexually Violent Predators, „Behavioral Sciences and the Law” 25, 2007, s. 437-448.
} 
pieczne są umieszczane w specjalnych ośrodkach zamkniętych, jak również na specjalnie dostosowanych oddziałach szpitali psychiatrycznych i w zakładach karnych ${ }^{15}$. W ramach pobytu we wspomnianych instytucjach sprawcy poddawani są oddziaływaniom psychoterapeutycznym, jak również farmakoterapii, przy czym te pierwsze działania są wobec sprawców podejmowane niezależnie od tego, czy wyrażą na nie zgodę, czy też nie ${ }^{16}$.

Wobec sprawców z grup mniejszego ryzyka recydywy mogą zostać ustalone odpowiednio mniej dolegliwe obowiązki, niewiążące się z pobytem w zakładzie zamkniętym. W stosunku do nich zostają ustanowione przez kuratora (ang. parole officer) działajacego w porozumieniu z sądem mniej lub bardziej intensywne warunki nadzoru. Mogą się one różnić w zakresie częstotliwości wykonania obowiązku meldowania się policji, jak również zakresem tzw. zakazów zbliżania się (do szkół, przedszkoli, kościołów, miejsca zamieszkania ofiary lub innych określonych miejsc), nałożeniem na sprawcę tzw. aresztu domowego, a także częstotliwością wizyt przydzielonego do nadzoru sprawcy funkcjonariusza. Wszelkie wykryte próby naruszenia warunków owego specyficznego nadzoru przez sprawcę powodują interwencję właściwych organów i moga skutkować zaostrzeniem wyznaczonych zasad przebywania sprawcy na wolności, a nawet skierowaniem do zakładu zamkniętego ${ }^{17}$.

Omówione wyżej procedury współwystępują nierzadko z rozwiązaniami uwzględnianymi w modelu leczenia i terapii, zmierzajacymi do poprawy sprawcy przez stosowanie wobec niego psychoterapii oraz terapii farmakologicznej ${ }^{18}$. Przede wszystkim jednak - i to wydaje się najistotniejszym aspektem nowoczesnych rozwiązań prawnych w zakresie form prawnokarnej reakcji wobec sprawców przestępstw seksualnych - poszczególne decyzje dotyczące sprawców są oparte na rzetelnej ocenie ryzyka recydywy. Dokonanie trafnej

15 C. Calkins Mercado, J. R. P. Ogloff, op. cit., s. 50-51.

${ }^{16}$ Zob. m.in. D. Doren, Recidivism Base Rates, Predictions of Sexual Offender Recidivism, and the "Sexual Predator” Commitment Laws, „Behavioral Sciences and the Law” 16, 1998, s. 97114; P. H. Witt, D. P. Greenfield, S. P. Hiscox, Cognitive/Behavioral Approaches to the Treatment Adult Sex Offenders, „The Journal of Psychiatry \& Law” 36/Summer 2008, s. 246.

${ }^{17}$ K. Tregilgas, op. cit., s. 743-745; C. Calkins Mercado, J. R. P. Ogloff, op. cit., s. 50-51.

18 K. Lewandowska, op. cit., s. 2-14; A. Morawska, op. cit., s. 1-14; K. K. Bonnar-Kidd, Sexual Offender Laws and Prevention of Sexual Violence or Recidivism, „American Journal of Public Health" 100, 2010, nr 3, s. 412-419; L. Ducat, S. Thomas, W. Blood, Sensationalising Sex Offenders and Sexual Recidivism: Impact of the Serious Sex Offender Monitoring Act 2005 on Media Reportage, „Australian Psychologist” 44, 2009, nr 3, s. 156-165; R. Geffner, K. Crumpton Franey, R. Falconer, Adult Sexual Offenders: Current Issues and Future Directions, „Journal of Child Sexual Abuse" 12, 2003, nr 3-4, s. 1-16; G. Robertiello, T. Kerry, Can We Profile Sex Offenders? A Review of Sex Offenders Typologies, „Aggression and Violent Behavior” 12, 2007, nr 5, s. 508-518; R. Mandeville-Norden, A. Beech, E. Hayes, Examining the Effectiveness of a UK Community-Based Sexual Offender Treatment Programme for Child Abusers, „Psychology, Crime \& Law” 14, 2008, nr 6, s. 493-512; R. K. Hanson et al., A Meta-Analysis of the Effectiveness of Treatment for Sexual Offenders: Risk, Need, and Responsivity, http://ocipep-bpiepc.gc.ca/res/cor/rep/_fl/200901-trt-so-eng.pdf; F. Losel, M. Schmucker, The Effectiveness of Treatment for Sexual Offenders: A Comprehensive Meta-Analysis, „Journal of Experimental Criminology” 1, 2005, nr 1, s. 117-146; R. K. Hanson et al., First Report of the Collaborative Outcome Data Project on the Effectiveness of Psychological Treatment for Sex Offenders, „Sexual Abuse: A Journal of Research and Treatment” 14, 2002, nr 2, s. 169-194. 
oceny ryzyka recydywy oraz właściwe zdefiniowanie potrzeb terapeutycznych sprawcy jest bowiem jednym z podstawowych elementów skutecznej reakcji wobec sprawców przestępstw seksualnych. Warto w tym miejscu pokrótce przedstawić najistotniejsze informacje dotyczace procedur i narzędzi, za pomocą których dokonuje się ocena ryzyka recydywy wśród sprawców przestępstw seksualnych. Należy wskazać, że sposoby i metody dokonywania tej oceny ulegały w ostatnim czasie szybkiemu i istotnemu rozwojowi.

Pierwotnie ocena ryzyka powrotu do przestępstwa dokonywana była właściwie bez żadnych wyspecjalizowanych narzędzi, w formie tzw. nieustrukturowanej oceny klinicznej (ang. unstructured clinical judgement) ${ }^{19}$. Wspomniane podejście polegało na sformułowaniu wniosków w zasadniczej części na podstawie informacji uzyskanych z przeprowadzonego ze sprawca wywiadu. Jakkolwiek zakres branych pod uwagę informacji mógł być znaczny, to jednak faktem jest, że stawiane wnioski stanowiły de facto czysto subiektywną ocenę, formułowana w zasadniczej mierze na podstawie doświadczenia osoby dokonujaccej oceny ${ }^{20}$.

Z czasem dominujacym sposobem dokonywania oceny było prowadzenie tzw. kierunkowanej oceny klinicznej (ang. guided clinical judgement), która polegała na tym, że wnioski stawiane były na podstawie wskazanych wyżej informacji, z ta jednak różnica, że poszukiwano bardziej konkretnych danych i opierano się na wiedzy odnośnie do statystycznie najczęściej występujących czynników ryzyka ${ }^{21}$. Obie metody spotykały się wszakże z zarzutami daleko posuniętej arbitralności oceny oraz koncentrowania się w całości na czynnikach z przeszłości, bez uwzględnienia zmian związanych z procesem leczenia czy terapii ${ }^{22}$.

Najbardziej świadomym podejściem do oceny ryzyka recydywy jest podejście anamnestyczne (ang. anamnestic risk assessment), w ramach którego historia życia sprawcy jest badana pod katem określonych predyspozycji i cech, a następnie ustala się, czy poszczególne zidentyfikowane czynniki ryzyka sa nadal obecne. W omawianym ujęciu poddaje się analizie czynniki zarówno bieżące, jak i historyczne. Zaletą omawianego podejścia jest fakt, że wskazuje ono pewien konkretny schemat prowadzacy do sformułowania finalnych wniosków, wadą - że w dalszym ciąu głównym źródłem informacji jest wywiad

19 A. R. Beech, T. Ward, The Integration of Etiology and Risk in Sexual Offenders: A Theoretical Framework, „Aggression and Violent Behavior” 10, 2004, s. 31-63; S. Hart, D. R. Laws, P. R. Kropp, The Risk-Need Model of Offender Rehabilitation, w: T. Ward, D. R. Laws, S. M. Hudson (red.), Theoretical Issues and Controversies in Sexual Deviance, Londyn 2003, s. 338-354; A. R. Beech, Case Material and Interview, w: C. Hollin (red.), Handbook of Offender Assessment and Treatment, Chichester 2001, s. 123-136.

${ }^{20}$ A. R. Beech, T. Ward, op. cit., s. 31-63; S. Hart, D. R. Laws, P. R. Kropp, op. cit., s. 338-354; A. R. Beech, op. cit., s. 123-136; T. Ward, D. L. L. Polaschek, A. R. Beech, Theories of Sexual Offending, Chapter 13. Theories of Risk, Wiley \& Sons 2006, s. 198.

${ }^{21}$ T. Ward, D. L. L. Polaschek, A. R. Beech, op. cit., s. 198; B. J. Limandri, D. J. Sheridan, Prediction Issues for Practitioners, w: J. C. Campbell (red.), Assessing Dangerousness: Violence by Sexual Offenders, Batterers and Child Abusers, Londyn 1995, s. 1-19.

22 J. K. Gierowski, L. Paprzycki, w: L. Paprzycki (red.) System prawa karnego. Środki zabezpieczajace, t. 7, Warszawa 2012, s. 196-197; A. R. Beech, T. Ward, op. cit., s. 34. 
przeprowadzany ze sprawca, a następnie wnioskowanie prowadzone przez osobę badajaccą ${ }^{23}$.

W ramach ujęcia anamnestycznego można wyróżnić dokonywanie oceny ukierunkowanej przez wyniki badań klinicznych (ang. research-guided clinical judgement ${ }^{24}$. W tym podejściu terapeuta wykorzystuje zestaw czynników, sformułowany a priori na podstawie badań klinicznych i teorii naukowych jako swoisty „przewodnik” do przeprowadzenia oceny ryzyka. Prawdopodobnie jednym z najbardziej znanych narzędzi służących dokonywaniu tego rodzaju ewaluacji jest SVR-20 (ang. sexual violence risk assessment instrument). Zawiera on listę elementów, które na podstawie wyników badań empirycznych okazały się predyktorem recydywy - zarówno statyczne (historyczne) czynniki ryzyka (np. dotychczasowe przestępstwa seksualne lub przemoc, problemy w związkach i relacjach interpersonalnych), jak i dynamiczne (inaczej: predyspozycje, np. postawy, które wspieraja popełnianie przestępstw seksualnych, uzależnienia) oraz czynniki ostre/nagłe (wyzwalające, np. utrata wsparcia ze strony najbliższych, częsty kontakt z potencjalnymi ofiarami) ${ }^{25}$.

W ostatnich latach coraz częściej daje się zaobserwować tendencję do tworzenia i rozwijania narzędzi służących do przewidywania ryzyka recydywy u przestępców seksualnych w sposób niemal mechaniczny, podejście to określa się mianem ang. purely actuarial approach (z braku dobrego polskiego odpowiednika zasadnym jest pozostać przy terminie oryginalnym ${ }^{26}$. W'́ród najbardziej znanych warto wskazać na: Rapid Risk Assessment for Sex Offender Recidivism ${ }^{27}$; Static-9928; Risk-Matrix 2000²9; The Sex Offence Risk Appraisal Guide (SORAG) ${ }^{30}$; The Minnesota Sex Offender Screening Tool-

${ }^{23}$ J. K. Gierowski, L. Paprzycki, op. cit., s. 197; A. R. Beech, T. Ward, op. cit., s. 34; T. Ward, D. L. L. Polaschek, A. R. Beech, op. cit., s. 198.

${ }_{24}$ A. R. Beech, T. Ward, op. cit., s. 34; T. Ward, D. L. L. Polaschek, A. R. Beech, op. cit., s. 198.

${ }^{25}$ D. P. Boer et al., Manual for the Sexual Violence Risk Scale-20., za: Mental Health, Law, and Policy Institute, Simon Fraser University, Burnaby, British Columbia, Canada 1997, dostępne na: www.sfu.ca/psychology/groups/mhlpi.; A. R. Beech, T. Ward, op. cit., s. 34; zob. także: K. Pospiszyl, Przestępstwa seksualne. Geneza, postacie, resocjalizacja oraz zabezpieczenia przed powrotnościa, Warszawa 2008, s. 195.

${ }^{26}$ T. Ward, D. L. L. Polaschek, A. R. Beech, op. cit., s. 199; A. R. Beech, T. Ward, op. cit., s. 34.

${ }^{27}$ R. K. Hanson, The Development of a Brief Actuarial Risk Scale for Sexual Offence Recidivism. User Report 1997-04, Ottawa: Department of the Solicitor General of Canada 1997 [Pobrano z:] www.sgc.gc.ca/publications/corrections/199704_e.pdf.; zob. także: K. Pospiszyl, op. cit., s. 194; R. K. Hanson, M. T. Bussiére, Predicting Relapse: A Meta-Analysis of Sexual Offender Recidivism Studies, „Journal of Consulting and Clinical Psychology” 66, 1998, s. 348-362.

${ }^{28}$ R. K. Hanson, D. Thornton, Static 99: Improving Actuarial Risk Assessments for Sex Offenders. User Report 99-02, Ottawa: Department of the Solicitor General of Canada 1999, www. sgc.gc.ca/publications/corrections/199902_e.pdf.; R. K. Hanson, D. Thornton, Improving Risk Assessments for Sex Offenders: A Comparison of Three Actuarial Scales, „Law and Human Behaviour" 2000, 24, s. 119-136.

${ }^{29}$ D. Thornton et al., Distinguishing and Combining Risks for Sexual and Violent Recidivism, w: R. Prentky et al., Understanding and Managing Sexually Coercive Behavior, „Annals of the New York Academy of Sciences" 2003, 989, s. 225-235.

${ }^{30}$ V. L. Quinsey et al., Violent Offenders: Appraising and Managing Risk, Washington 1998, za: T. Ward, D. L. L. Polaschek, A. R. Beech, op. cit., Chapter 13. Theories of Risk, Wiley \& Sons 2006, s. 199. 
-Revised (MnSOST-R) ${ }^{31}$. Wspomniane instrumenty skupiają się najczęściej na historycznych elementach, których znaczenie dla recydywy seksualnej zostało zidentyfikowane w badaniach naukowych. Wystapienie tych czynników i ich kodowanie według ustalonych zasad pozwalaja obliczyć prawdopodobieństwo ponownego popełnienia przestępstwa seksualnego i sklasyfikować sprawcę w jednej z kilku kategorii ryzyka ${ }^{32}$.

Dążąc do przezwyciężenia ograniczeń wspomnianych narzędzi, niektórzy badacze opracowali systemy klasyfikacji, które dodatkowo uwzględniały czynniki mogace ulegać zmianie, co miało doprowadzić do formułowania trafniejszych ocen ryzyka recydywy. W podejściu określanym mianem $\mathrm{z}$ ang. clinically adjusted actuarial approach uwzględniane są dynamiczne czynniki ryzyka, z jednej strony, aby wyznaczyć wyjściowy poziom zagrożenia recydywa, z drugiej zaś - aby korygować pierwotną ocenę na podstawie wyników prowadzonych oddziaływań specjalistycznych ${ }^{33}$. Do najbardziej znanych systemów, które zostały opracowane w oparciu o założenia ostatniego z wymienionych wyżej podejść, należą Sex Offender Treatment Evaluation Project (SOTEP) i stosowane w jego ramach testy psychometryczne używane w Wielkiej Brytanii do badania problemów psychicznych u sprawców wykorzystywania seksualnego dzieci ${ }^{34}$, Initial Deviance Assessment (IDA), w którym korzysta się z tzw. ustrukturowanego modelu oceny ryzyka (ang. structured risk assessment model) służącego do oceny ryzyka u sprawców wszystkich przestępstw seksualnych przez brytyjska służbę więzienna ${ }^{35}$, a także stosowany w Kanadzie Sex Offender Need Assessment Rating (SONAR) ${ }^{36}$. Każde z powyższych narzędzi może być stosowane nie tylko do możliwie wszechstronnej analizy ryzyka recydywy seksualnej w momencie podejmowania terapii, ale również do oceny, czy pacjent pozytywnie reaguje na prowadzone w stosunku do niego oddziaływania specjalistyczne. Warto w tym miejscu wskazać, że dokonywanie oceny i szacowanie ryzyka recydywy za pomoca przywołanych narzędzi określane jest mianem ustrukturowanej profesjonalnej

${ }^{31}$ D. L. Epperson, J. D. Kaul, D. Hesslton, Final Report on the Development of the Minnesota Sex Offending Screening Tool-Revised (MnSOST-R), St Paul, Minnesota Department of Corrections 1998, za: T. Ward, D. L. L. Polaschek, A. R. Beech, op. cit., s. 199.

${ }^{32}$ Zob. m.in. J. K. Gierowski, L. Paprzycki, w: L. Paprzycki (red.) System..., s. 197 i 200-201; A. R. Beech, T. Ward, op. cit., s. 34; T. Ward, D. L. L. Polaschek, A. R. Beech, op. cit., s. 199.

${ }_{33}$ A. R. Beech, T. Ward, op. cit., s. 34 i 36-39; T. Ward, D. L. L. Polaschek, A. R. Beech, op. cit., s. 199; A. R. Beech, D. D. Fisher, D. Thornton, Risk Assessment of Sex Offenders, „Professional Psychology: Research and Practice" 34, 2004, s. 339-352.

${ }^{34}$ A. R. Beech, D. Fisher, R. C. Beckett, STEP 3: An Evaluation of the Prison Sex Offender Treatment Programme, Londyn 1999, dostępne na: www.homeoffice.gov.uk/rds/pdfs/occ-step3.pdf.

${ }^{35}$ D. Thornton, Structured Risk Assessment, Sinclair Seminars Conference on Sex Offender Re-Offence Risk Prediction in Madison, Wisconsin 2000, dostępne na: www.sinclairseminars. com; D. Thornton, Constructing and Testing a Framework for Dynamic Risk Assessment, „Sexual Abuse: A Journal of Research and Treatment" 14, 2002, s. 139-154.

${ }^{36}$ R. K. Hanson, A. Harris, The Sex Offender Need Assessment Rating (SONAR): A Method for Measuring Change in Risk Levels, Ottawa 2000, dostępne na: www.sgc.gc.ca/publications/ corrections/200001b_e.asp. 
oceny ryzyka ${ }^{37}$. Skuteczność wymienionych instrumentów została ostatnio potwierdzona w badaniach empirycznych ${ }^{38}$.

Jak wyżej wspomniano, obecnie standardy postępowania ze sprawcami przestępstw seksualnych wymagają w pierwszej kolejności dokonania oceny (następnie jej bieżącego weryfikowania i uaktualniania) ryzyka recydywy, a później sformułowania „natężenia”, częstotliwości, jak również form i metod oddziaływań specjalistycznych, tak aby były one maksymalnie zindywidualizowane i dostosowane do potrzeb konkretnego sprawcy ${ }^{39}$.

Sensowność i celowość dokonywania gruntownej i rzetelnej oceny ryzyka recydywy jest nie do przecenienia, jeśli weźmie się pod uwagę skalę i zakres rozwiązań SVP, w szczególności zakres ingerencji w prawa i wolności człowieka i obywatela, następującej - jakkolwiek by było - po zakończeniu wykonywania kary. Po dokonaniu powyższych uwag wprowadzających warto zatem dokonać krótkiego przeglądu wybranych regulacji wprowadzanych przez ustawę z 22 listopada $2013 \mathrm{r}$.

Ustawa reguluje postępowanie wobec osób (art. 1), które spełniają łącznie następujace przesłanki:

1) odbywają prawomocnie orzeczoną karę pozbawienia wolności lub karę 25 lat pozbawienia wolności, wykonywaną w systemie terapeutycznym,

2) w trakcie postępowania wykonawczego występowały u nich zaburzenia psychiczne w postaci upośledzenia umysłowego, zaburzenia osobowości lub zaburzenia preferencji seksualnych,

3) stwierdzone u nich zaburzenia psychiczne mają taki charakter lub takie nasilenie, że zachodzi co najmniej wysokie prawdopodobieństwo popełnienia czynu zabronionego z użyciem przemocy lub groźbą jej użycia przeciwko życiu, zdrowiu lub wolności seksualnej, zagrożonego karą pozbawienia wolności, której górna granica wynosi co najmniej 10 lat. Środkami, które moga być stosowane wobec „osoby stwarzającej zagrożenie” są nadzór prewencyjny albo umieszczenie w Krajowym Ośrodku Zapobiegania Zachowaniom Dyssocjalnym (art. 3). Już w tym miejscu należy zwrócić uwagę, że teren Ośrodka i znajdujące się na nim pomieszczenia będą wyposażone w urządzenia monitorujące, umożliwiające stały nadzór nad osobami stwarzającymi zagrożenie umieszczonymi w Ośrodku oraz kontrolę stosowania przymusu bezpośredniego, a monitorowany obraz lub dźwięk jest utrwalany (art. 7). Skalę owego „sta-

${ }^{37}$ J. K. Gierowski, L. Paprzycki, op. cit., s. 197.

${ }^{38}$ A. R. Beech, D. D. Fisher, D. Thornton, op. cit., s. 339-352; zob. także: A. R. Beech, T. Ward, op. cit., s. 31-63; C. K. Gerhold, K. D. Browne, R. Beckett, Predicting Recidivism in Adolescent Sexual Offenders, „Aggression and Violent Behavior” 12, 2007, s. 427-438; D. Seifert, S. Möller-Mussavi, M. Wirtz, Risk Assessment of Sexual Offenders in German Forensic Institutions, „International Journal of Law and Psychiatry" 28, 2005, s. 650-660.

${ }^{39}$ D. A. Andrews, J. Bonta, The Psychology of Criminal Conduct, wyd. 3, Cincinnati 2003, za: T. Ward, D. L. L. Polaschek, A. R. Beech, op. cit., Chapter 16. The Risk-Need Treatment Model, s. 266-267; zob. także: L. Harkins, A. R. Beech, A Review of the Factors that Can Influence the Effectiveness of Sexual Offender Treatment: Risk, Need, Responsivity, and Process Issues, „Aggression and Violent Behavior" 12, 2007, s. 615-627; S. Hart, D. R. Laws, P. R. Kropp, The Risk-Need Model of Offender Rehabilitation, w: T. Ward, D. R. Laws, S. M. Hudson (red.), Theoretical Issues and Controversies in Sexual Deviance, London 2003, s. 338-354. 
łego nadzoru" oddaje przepis, w myśl którego z monitoringu nie są wyłączone pomieszczenia lub ich części przeznaczone do celów sanitarno-higienicznych, a jedynie obraz jest wtedy przekazywany w sposób uniemożliwiający ukazywanie intymnych części ciała ludzkiego oraz intymnych czynności fizjologicznych (art. 7 ust. 3).

Podstawa wszczęcia postępowania w przedmiocie uznania osoby za stwarzająca zagrożenie jest wniosek dyrektora zakładu karnego, oparty na sporządzonej $\mathrm{w}$ trakcie postępowania wykonawczego opinii psychiatrycznej i psychologicznej o stanie zdrowia osoby, z której to opinii wynika, że osoba spełnia przesłanki określone w art. 1 pkt 2 i 3. Do wniosku dołącza się opinię, a także informację o wynikach dotychczas stosowanych programów terapeutycznych i postępach w resocjalizacji (art. 9). W celu ustalenia, czy osoba, której dotyczy wniosek, wykazuje zaburzenia, o których mowa w art. 1 pkt 3, w postaci upośledzenia umysłowego, zaburzenia osobowości lub zaburzenia preferencji seksualnych sąd powołuje dwóch biegłych lekarzy psychiatrów, a w sprawach osób z zaburzeniami osobowości - ponadto biegłego psychologa, a w sprawach osób z zaburzeniami preferencji seksualnych - ponadto biegłego lekarza seksuologa lub certyfikowanego psychologa seksuologa (art. 11). Zgodnie z art. 14 sąd, dokonując oceny, bierze pod uwagę całokształt okoliczności ustalonych w sprawie, a w szczególności uzyskane opinie biegłych, a także wyniki prowadzonego dotychczas postępowania terapeutycznego oraz możliwość efektywnego poddania się przez tę osobę postępowaniu terapeutycznemu na wolności. W zależności od stopnia prawdopodobieństwa popełnienia przez osobę czynu zabronionego z użyciem przemocy lub groźbą jej użycia przeciwko życiu, zdrowiu lub wolności seksualnej, zagrożonego kara pozbawienia wolności, której górna granica wynosi co najmniej 10 lat, sąd orzeka o zastosowaniu bądź nadzoru prewencyjnego (wysokie prawdopodobieństwo), bądź o umieszczeniu w Ośrodku (bardzo wysokie prawdopodobieństwo). Warto w tym miejscu zaznaczyć, że nadzór prewencyjny i umieszczenie w Ośrodku orzeka się bez określenia terminu.

Na szczególną uwagę zasługuje fakt, że wydając postanowienie o uznaniu osoby za osobę stwarzająca zagrożenie, sąd zarządza: 1) pobranie od tej osoby wymazu ze śluzówki policzków w celu przeprowadzenia analizy kwasu dezoksyrybonukleinowego (DNA); 2) pobranie od tej osoby odcisków linii papilarnych; 3) wykonanie zdjęć, szkiców i opisów wizerunku tej osoby; 4) umieszczenie wyników analizy DNA, odcisków linii papilarnych, zdjęć, szkiców i opisów wizerunków w odpowiednich bazach i zbiorach danych, o których mowa w ustawie z 6 kwietnia $1990 \mathrm{r}$. o Policji ${ }^{40}$.

W zakresie dalszych istotnych ograniczeń, jakim poddawane są osoby przebywające w Krajowym Ośrodku Zapobiegania Zachowaniom Dyssocjalnym warto wskazać na zakaz posiadania przedmiotów niebezpiecznych i możliwość

${ }^{40} \mathrm{~W}$ ramach realizacji celów nadzoru prewencyjnego policja może również prowadzić czynności operacyjno-rozpoznawcze dotyczące osoby stwarzającej zagrożenie, a także weryfikować, gromadzić i przetwarzać informacje udzielane przez tę osobę oraz uzyskane w wyniku czynności operacyjno-rozpoznawczych (art. 23). 
kontroli pomieszczeń, w których osoba przebywa (art. 28), możliwość ograniczenia kontaktów z innymi osobami (art. 29), a przede wszystkim uprawnienie do stosowania wobec osób stwarzających zagrożenie szerokiego wachlarza środków przymusu bezpośredniego (art. 34 i n.).

Nawet powierzchowna analiza przepisów ustawy (bardziej szczegółowe omówienie przekracza ramy niniejszego artykułu) pozwala wywodzić wniosek, że zakres ingerencji w prawa i wolności człowieka i obywatela, przewidziany przez omawiany akt prawny jest znaczny. Niezależnie od bardzo poważnych wątpliwości co do zgodności proponowanych rozwiązań z Konstytucją RP, które zostały pominięte $\mathrm{w}$ niniejszym artykule, albowiem $\mathrm{z}$ pewnościa - $\mathrm{w}$ razie wejścia ustawy w życie - staną się one przedmiotem wnikliwego badania przez Trybunał Konstytucyjny, warto zwrócić uwagę na jeden z najbardziej istotnych aspektów komentowanej regulacji.

W pierwszej kolejności należy wskazać, że obecnie w Polsce nie są stosowane najnowocześniejsze narzędzia służące do trafnej i rzetelnej oceny ryzyka recydywy wśród sprawców przestępstw seksualnych - brak jest ich tłumaczenia, a przede wszystkim normalizacji, co prowadzi do wniosku, że w warunkach polskich w dalszym ciagu mamy do czynienia z nieustrukturowaną ocena kliniczna, której trafność i rzetelność są dalece niewystarczające. Jeżeli zatem wobec sprawcy po zakończeniu odbywania przez nich kary pozbawienia wolności mają zostać zastosowane szczególnie dotkliwe, związane z niezwykle daleko idącą ingerencją w jego prawa i wolności, środki oddziaływania, to należy wymagać, aby ocena, czy osoba taka rzeczywiście stwarza co najmniej wysokie prawdopodobieństwo popełnienia czynu zabronionego z użyciem przemocy lub groźbą jej użycia przeciwko życiu, zdrowiu lub wolności seksualnej (zagrożonego karą pozbawienia wolności, której górna granica wynosi co najmniej 10 lat), dokonywana była w sposób metodologicznie poprawny, z wykorzystaniem najpełniejszej dostępnej wiedzy na temat oceny ryzyka recydywy - czyli de facto właśnie oceny zagrożenia ze strony danego sprawcy. Kryteria, na podstawie których dokonywane będą te ustalenia w toku procedury w przedmiocie uznania sprawcy za osobę stwarzająca zagrożenie, muszą być obiektywne (lub chociaż zobiektywizowane), w przypadku zaś stosowanej w Polsce ocenie klinicznej z cała pewnością takie nie sa.

Jeżeli nawet ocena stopnia zagrożenia ze strony danego sprawcy byłaby dokonywana $\mathrm{z}$ uwzględnieniem najnowszego dorobku wiedzy i osiagnięć nauki w zakresie oceny ryzyka recydywy, to przepisy ustawy generuja kolejne problemy, a to w postaci całkowicie chybionego powiązania stopnia zagrożenia ze strony sprawcy z ustawowym wymiarem kary za czyny, jakich może się dopuścić osoba badana. Jest to problematyczne, gdyż przy ocenie ryzyka recydywy nawet najlepsze dostępne narzędzia diagnostyczne pozwalają obecnie co najwyżej przewidywać prawdopodobieństwo popełniania zachowań o określonym charakterze, ewentualnie zachowań konkretnego rodzaju (np. zachowania z użyciem przemocy, zachowania noszace znamiona agresji seksualnej, zachowania seksualne wobec dzieci), co jednak nie pozwala wywodzić prostego wniosku, że będzie to czyn zagrożony taka, a nie inną karą pozbawienia wol- 
ności. Powiązanie sfery diagnostyki psychologicznej i medycznej z kategoriami stricte prawnymi wydaje się w najwyższym stopniu błędne, a przede wszystkim problematyczne w perspektywie stosowania omawianych regulacji ${ }^{41}$.

Wątpliwości, które pozwalają domyślić się rzeczywistego celu ustawy, wzmaga nawet powierzchowne porównanie przewidzianych w ustawie form oddziaływania wobec sprawców, tj. nadzoru prewencyjnego i umieszczenia w Krajowym Ośrodku Zapobiegania Zachowaniom Dyssocjalnym. Trzeba bowiem wskazać, że zgodnie z art. 16 ustawy, orzekając o zastosowaniu nadzoru prewencyjnego, sąd może nałożyć na osobę stwarzającą zagrożenie obowiązek poddania się odpowiedniemu postępowaniu terapeutycznemu. Fakt, że nałożenie obowiązku poddania się oddziaływaniom terapeutycznym jest fakultatywne, stanowi, jak się wydaje, istotną niespójność: skoro nawet sprawcy majaccy podlegać nadzorowi prewencyjnemu to sprawcy, których cechuje wysokie prawdopodobieństwo recydywy, to nasuwa się pytanie, dlaczego także w stosunku do nich nie jest przewidziana jakakolwiek forma oddziaływań terapeutycznych i leczniczych, a jedynie swoisty dozór policji. Proponowane rozwiązania są zastanawiające także i z tego względu, że - jak pokazują wyniki badań - wszelkie formy nadzoru, dozoru, rejestracji, a nawet monitorowania GPS sprawców same w sobie (bez ich uzupełnienia o terapię i leczenie farmakologiczne) nie stanowią wystarczającego środka służącego zapobiegnięciu ponownemu popełnieniu przestępstwa ${ }^{42}$. Okoliczność ta dobitnie wskazuje na całkowitą nieznajomość projektodawców problematyki trafnej i adekwatnej prawnokarnej reakcji wobec sprawców przestępstw seksualnych.

W niniejszym artykule zwrócono uwagę przede wszystkim na jeden z praktycznych aspektów regulacji zaproponowanych w ustawie o postępowaniu wobec osób z zaburzeniami psychicznymi stwarzających zagrożenie życia, zdrowia lub wolności seksualnej innych osób, tj. na kryteria kwalifikujace do pobytu w Ośrodku lub do zastosowania nadzoru prewencyjnego oraz możliwe trudności w dokonywaniu zobiektywizowanej oceny ryzyka recydywy w warunkach polskich. Niezależnie od tego warto zasygnalizować również dalsze kwestie praktyczne stosowania omawianych przepisów: czy plan terapeutyczny dla osoby stwarzajacej zagrożenie będzie konstruowany z uwzględnieniem zasad R-N-R (ang. risk-need-responsivity) ${ }^{43}$; czy w terapii sprawców stosowane będzie podejście o dowiedzionej skuteczności, tj. poznawczo-behawioralne ${ }^{44}$,

\footnotetext{
${ }^{41} \mathrm{Na}$ wątpliwości związane $\mathrm{z}$ ustawowym powiązaniem pojęć, metod, technik oraz narządzi z zakresu psychologii i medycyny, z kategoriami prawnymi wskazywali w ostatnim czasie m.in. J. K. Gierowski i L. Paprzycki w odniesieniu do aktualnie obowiązującej konstrukcji przepisu art. 95a k.k.; zob. J. K.Gierowski, L. Paprzycki, op. cit., s. 235.

${ }^{42}$ T. A. Gannon, A. R. Beech, T. Ward, Does the Polygraph Lead to Better Risk Prediction for Sexual Offenders?, „Aggression and Violent Behavior” 13, 2008, s. 29-44; R. Lieb, H. Kemshall, T. Thomas, Post-Release Controls for Sex Offenders in the U.S. and UK, „International Journal of Law and Psychiatry" 34, 2011, nr 3, s. 226-232; D. M. Button, M. DeMichele, B. K. Payne, Using Electronic Monitoring to Supervise Sex Offenders: Legislative Patterns and Implications for Community Corrections Officers, „Criminal Justice Policy Review” 20, 2009, nr 4, s. 414-436 oraz cytowana tam literatura.

${ }^{43}$ R. K. Hanson et al., First report..., s. 169-194; F. Lösel, M. Schmucker, op. cit., s. 117-146; L. Harkins, A. Beech, Measurement of the Effectiveness of Sex Offender Treatment, „Aggression and Violent Behavior" 12, 2007, nr 1, s. 36-44.

${ }^{44}$ R. K. Hanson et al., First report..., s. 169-194; F. Lösel, M. Schmucker, op. cit., s. 117-146;
} 
jak w praktyce będzie przebiegać wykonywanie nadzoru prewencyjnego i czy w rzeczywistości nie będzie ono przypominało wykonywania zwykłego dozoru, to tylko niektóre z kwestii, które z cała pewnościa stanowić będą o finalnej ocenie omawianej ustawy. Nie bez znaczenia sa również silnie podkreślane wątpliwości, co do zgodności projektowanych przepisów w Konstytucją RP.

W świetle powyższych rozważań należy wskazać, że nawet jeśli ustawa miałaby stanowić krok w kierunku stworzenia spójnego i przemyślanego systemu form prawnokarnej reakcji wobec sprawców przestępstw seksualnych, to widoczne na pierwszy rzut oka oderwanie przepisów tej ustawy od realiów praktyki, jak również wyrażane wśród ekspertów przekonanie, że omawiany akt prawny został uchwalony jedynie (albo w zasadniczej części) po to, by określona grupa sprawców nie wyszła na wolność, kłaść się będą cieniem na całości regulacji wprowadzanych przez komentowaną ustawę.

mgr Maciej Bocheński

Uniwersytet Jagielloński

maciej.bochenski@uj.edu.pl

\title{
WHO WILL BE ‘HEALED’ BY THE NATIONAL CENTRE FOR THE PREVENTION OF DISSOCIAL BEHAVIOUR?
}

\author{
Sum mary
}

The issue of a legal response to sex offenders has been present in the social and academic discourse for a long time. Despite severe criticism directed against the Polish legislature after the adoption of the earlier regulation on combating sex offenders, the President of the Republic of Poland signed the Act on Proceedings against Persons with Mental Disorders Posing a Threat to Life, Health or Sexual Freedom of Others. Legal institutions for which this law provides for are part of the solution collectively referred to as the (SVP $<$ Sexually Violent Predator $>$ Legislation). While the idea of such regulations shall not be assessed as unambiguously negative, an important issue that may arise on the basis of implementing the provisions of this Act, is the fact that there are no modern tools of risk assessment in practical use or available in the Polish prison system and forensic psychiatry. Consequently, classifying sex offenders as SVPs must be questioned, especially in view of the significant scope of the planned interference with their civil rights and liberties. The article presents the basic principles on the SVP Legislation, as well as basic information on the risk assessment of recidivism among sex offenders. It then summarises the theoretical issues present in Polish solutions, as well as the Polish practice of assessing the risk of recidivism.

L. Harkins, A. Beech, op. cit., s. 36-44. 
Copyright of Journal of Law, Economics and Sociology is the property of Faculty of Law and Administration of Adam Mickiewicz University in Poznan and its content may not be copied or emailed to multiple sites or posted to a listserv without the copyright holder's express written permission. However, users may print, download, or email articles for individual use.

Właścicielem praw autorskich do „Ruchu Prawniczego, Ekonomicznego i Socjologicznego” jest Wydział Prawa i Administracji Uniwersytetu im. Adama Mickiewicza w Poznaniu. Zawartość czasopisma nie może być kopiowana, przesyłana do innych stron internetowych bądź zamieszczana na blogach bez pisemnej zgody wydawcy. Niemniej artykuły można drukować, kopiować lub przesyłać w formie elektronicznej na własny użytek. 